\title{
Assessment of Knowledge on the Mode of Transmissions and Preventions of Hepatitis-B Among Undergraduate Students in Nigeria
}

\author{
Fasoranti Afolabi Joseph (iD)
}

Department of Human Kinetics and Health Education, University of Lagos, Lagos, Nigeria.

\begin{tabular}{|c|c|}
\hline$A R T I C L E I N F O$ & $A B S T R A C T$ \\
\hline $\begin{array}{l}\text { Article History: } \\
\text { Received: } 17 \text { Sep } 2020 \\
\text { Revised: } 13 \text { Jan } 2021 \\
\text { Accepted: } 14 \text { Mar } 2021\end{array}$ & $\begin{array}{l}\text { Background: Hepatitis B, which is caused by the Hepatitis B virus (HBV), is a } \\
\text { global health problem that has resulted in high morbidity and mortality with } \\
\text { knowledge and awareness about the occurrence and mode of transmissions } \\
\text { relatively low among the populace. Therefore, this study examined knowledge } \\
\text { on the mode of transmission and preventions of hepatitis B among } \\
\text { undergraduate students in Lagos, Nigeria. }\end{array}$ \\
\hline $\begin{array}{l}\text { *Corresponding Author: } \\
\text { Fasoranti Afolabi Joseph } \\
\text { Email: } \\
\text { fasorantiafolabi@yahoo.com } \\
\text { Tel: }+2347066086809\end{array}$ & $\begin{array}{l}\text { Methods: The cross-sectional descriptive research was used, and a multi-stage } \\
\text { sampling technique was adopted to select three hundred respondents which } \\
\text { comprised male and female from three tertiary institutions in Lagos state in } \\
\text { 2019. Hepatitis B Knowledge Questionnaire with a reliability index of } 0.74 \\
\text { was used for data collection. The descriptive statistics of frequency count and } \\
\text { percentages was used to analyse the demographic characteristics of } \\
\text { respondents while the chi-square test was used to determine associations } \\
\text { between categorical variables. }\end{array}$ \\
\hline $\begin{array}{l}\text { Citation: } \\
\text { Afolabi Joseph F. Assessment } \\
\text { of Knowledge on the Mode of } \\
\text { Transmissions and Preventions } \\
\text { of Hepatitis-B Among }\end{array}$ & $\begin{array}{l}\text { Results: The results revealed that a high proportion of the respondents had } \\
\text { poor knowledge about the transmission and prevention of hepatitis B. The } \\
\text { result revealed that the p-value } \leq 0.05 \text { was considered statistically insignificant. } \\
\text { Therefore, the study revealed that there is no significant relationship between }\end{array}$ \\
\hline $\begin{array}{l}\text { Undergraduate Students in } \\
\text { Nigeria. Journal of Social } \\
\text { Behavior and Community } \\
\text { Health (JSBCH). 2021; 5(1): } \\
\text { 596-601. }\end{array}$ & $\begin{array}{l}\text { Conclusion: A critical level of public awareness and vaccination coverage, } \\
\text { particularly among students, is essential to decrease Lagos' burden. } \\
\text { Keywords: Undergraduate Students, Hepatitis B, Knowledge, Prevention, } \\
\text { Transmission }\end{array}$ \\
\hline
\end{tabular}




\section{Introduction}

Hepatitis B virus (HBV) is one of the major public health problems in the world. World Health Organisation (WHO, 2017) estimated that about one-third of the world population is infected with HBV. Of these, about 360 million people are chronic carriers and are at risk of developing liver diseases like cirrhosis and hepatocellular carcinoma (HCC). According to the Center for Disease Control (2017), about 120,000 of Nigeria's population are affected with Hepatitis B, more than 50,000 suffered from lifelong chronic infection, and more than 12,000 individuals die due to HBVinduced infections. Therefore, HBV remains the major cause of liver-related morbidity and mortality.

Hepatitis B virus is associated with acute viral hepatitis - an illness that begins with general illhealth, loss of appetite, nausea, vomiting, body aches, mild fever, and dark urine, and then progresses to the development of jaundice. It has been noted that itchy skin has been an indication as a possible symptom of all hepatitis virus types. A few people may have more severe liver disease (fulminant hepatic failure) and may die as a result. The infection may be entirely asymptomatic and may go unrecognized. Chronic infection with hepatitis B virus may either be asymptomatic or associated with chronic inflammation of the liver (chronic hepatitis), leading to cirrhosis for several years. This type of infection dramatically increases the incidence of hepatocellular carcinoma (WHO, 2017).

Hepatitis B virus is a DNA virus known to be 100 times more infectious than the human immunodeficiency virus (Okonkwo et al., 2017). One of the most important priorities for preventing, controlling, and eliminating HBV is to know the factors involved in disease transmission, especially in the endemic region. HBV is contagious and easy to be transmitted from one infected individual to another through blood or other body fluids during sexual and non-sexual contacts, mother-to-child transmission, and unsterilized equipment (Aslam et al., 2015). The main transmission routes include prenatal infection, skin and mucous membrane infections caused by contaminated blood or body fluids, sexual contacts, and injection. Besides, tattooing, body piercing, acupuncture, dialysis, and even using a syringe can be the source of HBV transmission. HBV cannot be transmitted by holding hands, sharing food, kissing, hugging, sneezing, or breastfeeding.

HBV ranks second, after tobacco, on the list of known carcinogenic agents that affect humans. Furthermore, infection with HBV constitutes the first etiology of hepatocellular carcinoma and the tenth leading cause of death worldwide (Okwara et al., 2012). However, other protective measures include condom use during sexual intercourse, handwashing, avoiding sharing of needles and personal care items like toothbrush and razor, using protective barriers such as gloves, and avoiding tattooing as much as possible, especially when the sterility of the tattooing equipment is not guaranteed, appropriate sterilization of medical equipment, and a suitable hospital waste management. Due to the latest trends in fashions, such as body piercing and explosives makeups through the use of sharp objects, students are at high risks of contracting and spreading the disease (Al-Hazmi, 2015).

Efforts aimed at increasing community awareness and knowledge of HBV transmission and prevention is important, especially among young adults. Exposing young adults to HB information is important because it is at this stage that they initiate interest in sexual relationships and tend to explore and experiment with sex, which is a risk factor of contraction and transmission of hepatitis B (Eredoro \& Egbochukwu, 2017). it is also at this stage that most detrimental lifelong lifestyles and behaviors are adopted, like substance use, promiscuity which is also predisposing factors for the contraction of $\mathrm{HBV}$ infections. Adequate knowledge on the mode of transmission and prevention is the only safeguard against the epidemic of viral hepatitis. Knowing these facts, having proper attitudes and behavior is critical to 
prevent the spread of the disease. Although many studies have assessed knowledge of HBV among medical students in the world and Nigeria, few have been done among other tertiary students. It is hoped that information from this study will be useful in developing need-based educational materials on the Hepatitis B virus. Therefore, the study examined knowledge of the mode of transmission and prevention of hepatitis B among undergraduate students. It also examined significant relationship between gender and knowledge of hepatitis B among undergraduate students.

\section{Methods}

A cross-sectional descriptive study was carried among undergraduate students in three selected tertiary institutions in Lagos State, Nigeria. Three hundred respondents were selected randomly using a convenient sampling technique from the University of Lagos, Yaba College of Technology, and Federal College of Education, Akoka. Although 300 questionnaires were administered, only 296 of them were returned and correctly filled.Hepatitis B Questionnaire was used for data collection. In addition to basic demographic characteristics, the questionnaire included 12 questions about the mode of transmission (6 questions) and prevention of HBV (6 questions). The 12 questions included both correct and wrong statements on modes of transmission and prevention of HBV. The students were asked to answer each question with 'yes' or 'no.' Each correct answer was given a score of ' 1 ' while a wrong answer was given a score of '0'. Students' knowledge was classified into three levels according to the total score obtained; a total score of 0-4 was regarded as poor knowledge, 58 as acceptable knowledge, and 9 and above as good knowledge.

The questionnaire was reviewed by two other experts from the Health Education Unit. It was also pre-tested on ten students of Saint Augustine College of Education. A reliability coefficient of 0.74 was obtained. The anonymity of respondents was assured, and their verbal consent was obtained. The Research Ethics Committee of Lagos State University Teaching Hospital approved the study. The copies of the questionnaire were administered by the researchers. The statistical package for social sciences version 20 was used for data entry and analysis. Descriptive statistics, including frequencies and pie-chart, were used to analyze the demographic data, while the chi-square test was used to determine associations between categorical variables. A p-value $\leq 0.05$ was considered statistically significant.

\section{Results}

According to the results of the demographic date of the respondents presented in table 1, 172 of the respondents $(58.11 \%)$ were male while 124 of the respondents $(41.89 \%)$ were female.

Based on the figure 1, it shows that the majority of the respondents, 167 (56.42\%), fell within the age range of $19-25$ years, $75(25.34 \%)$ less than 18 years old, while $54(18.24 \%)$ of the respondents were 25 years and above.

Table 1. Demographic Distribution by Gender

\begin{tabular}{lcc} 
Gender & Frequency & Percentage \\
\hline Male & 172 & 58.11 \\
Female & 124 & 41.89 \\
Total & 296 & 100 \\
\hline
\end{tabular}




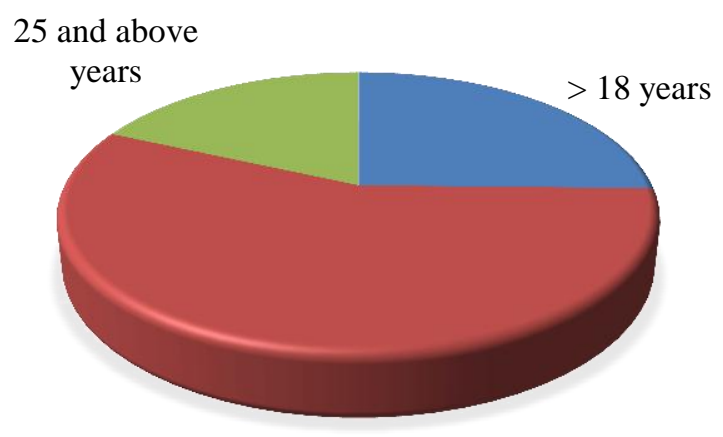

19- 25 years

Figure 1. Pie-chart Presentation of Respondents by Age

\section{Table 2. Distribution of Sample by General Knowledge about HBV $(\mathrm{n}=\mathbf{2 9 6})$}

Knowledge about mode of transmission of Hepatitis B virus $\mathrm{HBV}$ is more easily spread from person to person than AIDS HBV carriers (although they look healthy) can easily infect others $98 \quad 33.11 \quad 198$

HBV can be spread by eating food prepared by an infected person

HBV can be spread by kissing an infected person

$45.27 \quad 162$

HBV can be spread by being coughed on by an infected person

Knowledge about Hepatitis B virus prevention

People with HBV can be infected for life

$94 \quad 31.76 \quad 202$

40.88

Using sterilized sharp objects can help to prevent HBV

Handwashing and hygiene practices can prevent HBV

HBV disease can be cured

$\begin{array}{llll}38 & 12.84 & 258 & 87.16\end{array}$

A high proportion of the study participants (68.89\%) are not aware that HBV is more easily spread from person to person than HIV, while about $48.99 \%$ of the respondents knew that healthy carriers of HBV could infect others. The study also revealed that over $45 \%$ of participants thought that people with HBV could spread the virus by eating food prepared by an infected person, while $69.93 \%$ of the respondents reported that HBV could be spread by kissing an infected person. In terms of knowledge about preventive measures, $85.81 \%$ of respondents stated that using sterilized sharp objects such as razor blades, needles, and clippers can help in preventing HBV, while $57.77 \%$ of the participants correctly identified vaccination as a way of preventing $\mathrm{HBV}$ infection, and $93.58 \%$ of students HBV can be prevented through abstinence. 38 (12.84\%) of the respondents have been vaccinated against $\mathrm{HBV}$, while $87.16 \%$ of the respondents have not received the vaccine, which is a serious concern. Details of students' knowledge about HBV are shown in Table 2. 
Table 3. Relationship between Knowledge Score and Gender of the Study Sample ( $n=296)$

\begin{tabular}{|c|c|c|c|c|c|c|c|c|}
\hline \multirow{2}{*}{ Variable } & \multirow{2}{*}{$\mathbf{N}$} & \multirow{2}{*}{$\begin{array}{c}\text { Poor }(0-4) \\
\text { No }\end{array}$} & \multirow[b]{2}{*}{$\%$} & \multicolumn{2}{|l|}{ Moderate (5-8) } & \multicolumn{2}{|c|}{ Good (9-12) } & \multirow{2}{*}{ P value } \\
\hline & & & & No & $\%$ & No & $\%$ & \\
\hline \multicolumn{9}{|l|}{ Gender } \\
\hline Male & 172 & 16 & 9.30 & 124 & 72.10 & 32 & 18.60 & 0.086 \\
\hline Female & 124 & 14 & 11.29 & 72 & 58.06 & 38 & 30.65 & \\
\hline Total & 296 & 30 & 10.14 & 196 & 66.22 & 70 & 23.64 & \\
\hline
\end{tabular}

At 0.05 significant level with a p-value of 0.086 , in the 3 table revealed that there was no statistically significant relationship between the gender of respondents and their knowledge scores.

\section{Discussion}

The result of this study reveals that most of the students have acceptable knowledge on the mode of transmission and prevention of the HBV However, only $25 \%$ of the students know that there is no cure for Hepatitis B. while there may be indications that HBV may be controlled or possibly eradicated in the nearest future, current antiviral strategies for its treatment are either poorly affective or only effective for non-curative suppression of the viral replication thereby reducing complications, and reduction of inflammation of liver (Eredoro \& Egbochukwu, 2017). Assessing people's knowledge is a useful step to assess the extent to which an individual or community is in a position to adopt a risk-free disease behavior for this disease (El-Nasser \& El Baset, 2013). Based on this assertion, the study participants had appreciable knowledge of Hepatitis B.

In this study, $51 \%$ of the respondents opined that HBV carriers (although they look healthy) could not easily infect others which negates the fact, according to WHO (2017) findings that healthy carriers of HBV can spread the disease to others. A similar study by Aslam et al. (2015) also reported that carriers of HBV are mostly the transmitter of the virus due to the unawareness of their health status. The majority of the respondents also acknowledged that Hepatitis B can be prevented through the HBV vaccine, which also falls in line with the study of Samuel et al. (2009), who reported that most of the participants examined in their study had significant knowledge that HBV vaccines can help in preventing hepatitis B. Less than $15 \%$ of the respondents have received HBV vaccines, which is of great concern towards eradicating this deadly scourge. Most of the studies carried out within Nigeria shows that although people are aware of Hepatitis B, the level of vaccine intake is still very poor, which is in line with the study (Erodoro \& Egbochukwu, 2017; Okeke et al., 2008; Amorha et al., 2017).

This study also pointed out that there was no statistically significant relationship between gender of students and their knowledge score on the mode of transmission and prevention of Hepatitis B. the finding aligns with a similar study carried out by Al-Ajlan (2011), who reported that gender variable had no significant association with knowledge of hepatitis B among medical students in Saudi Arabia. Based on this assertion, the study established that the female and male respondents' knowledge on mode of transmission and prevention of $\mathrm{HB}$ does not differ.

\section{Conclusion}

This study shows that there was good knowledge on hepatitis B among undergraduate students in selected tertiary institutions in Lagos state. Although, the students had more knowledge on precautions than transmission and consequences of the disease. The level of Hepatitis B vaccination among the respondents is extremely low. Therefore, there is an urgent need for the government, public health officers, and other stakeholders to raise awareness of the importance of HBV vaccines. This will further help in curtailing the prevalence of the disease. A critical level of public awareness and vaccination coverage, particularly among students, is essential 
to decrease Lagos' burden. Also, extensive health education campaigns on the mode of transmission and preventions to manage all aspects of knowledge, attitude, and practice towards HBV should be emphasized.

\section{Conflict of interest}

Author declare no conflict of interest during the study period.

\section{Acknowledgments}

The researcher would like to thank all the participants who contributed to the study.

\section{Authors' Contribution}

This article has one author.

The author read and approved the final manuscript and is responsible about any question related to article.

\section{References}

Al-Ajlan, A. (2011). Prevalence of hepatitis B and C among students of health colleges in Saudi Arabia. East Mediterrian Health Journal, 17(10), 759-762.

Al-Hazmi, A. (2015). Knwledge, attitudes, and practice of medical students regarding occupational risks of hepatitis B virus in college of Medicine, Aljouf University. Annal of Medical and Health Sccience Research, 5 (1), 13-19.

Amorha, K.C., Chiebue, M.I., Ayogu, E. E., Ukoha-Kalu, O.B., Okonta, M.J. (2017). Knowledge, attitudes and practice of undergraduate students in University of Nigeria Enugu Campus towards Hepatitis B. IOSR Journal of Pharmacy and Biological Sciences, 12 (3), 66-71.

Aslam, G., Soniha, A., Yasmeen, I., Akhtar, A.S. (2015). Knowledge and awareness of Hepatitis B among students of a Public Sector University. ISRA Medical Journal, 7 (2), 95-100.

Centers for Disease Control and Prevention (2017). HBV a silent killer. Available from http://www.cdc.gov/ncidod/disease. Retrieved on $10^{\text {th }}$ May, 2018.

El-Nasser, G.A., El-Baset, E.A. (2013). Assessment of students' knowledge and attitude toward hepatitis B and C in Sohag University/Egypt. Kufa Journal for Nursing Sciences, 3 (1), 1-14.

Eredoro, C.O., Egbochukwu, O.O. (2017). Awareness and opinions about hepatitis B among secondary school teachers in Irepodun local government area of Kwara state, Nigeria. Health Science Journal, 11(5), 1-8

Okeke, E.N., Ladep, N.G., Agaba, E., Malu, A.O. (2008). Hepatitis B vaccination status and needle stick injuries among medical students in a Nigerian Universities. Nigerian Journal of Medicine, 17 (3), 330-332.

Okonkwo, U.C., Ngim, O.E., Osim, H., Inyamah, M.A., Esu, E., Ndoma-egba, R., Ezedinachi, E. (2017). Knowledge of Hepatitis B virus among traders. Nigerian Journal of Clinical Practice, 20 (4), 415-420

Okwara, E.C., Enwere, O.O., Diwe, C.K., Azike, J.E., Chukwulebe, A.E. (2012). Theatre and Laboratory workers' awareness of and safety practices against Hepatitis $\mathrm{B}$ and $\mathrm{C}$ infection in a sub-urban University Teaching Hospital in Nigeria. Pan African Medical Journal, 13(1), 28.

Samir, M.O., Abubakir, M.S., Nazar, P.S. (2013). Knowledge about Hepatitis B infection among Medical Students in Erbil City, Iraq. European Scientific Journal, 3, 299-305.

Samuel, S.O., Aderibigbe, S.A. Salami, T.A., Babatunde, O.A. (2009). Health workers' knowledge, attitude and behaviour towards Hepatitis B infection in Southern Nigeria. International Journal of Medicine and Medical Sciences, 1, (10), 418-424.

World Health Organization. (2016). Hepatitis B fact sheet. WHO, Geneva. 